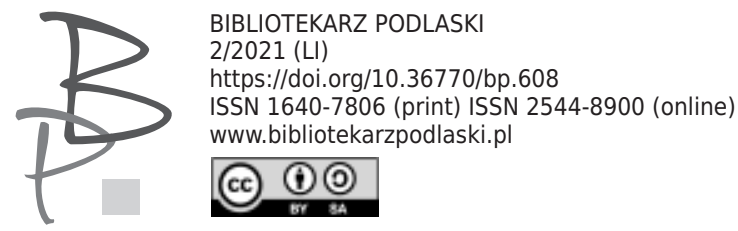

\title{
Marek Rutkowski*
}

Akademia Wychowania Fizycznego im. Bronisława Czecha w Krakowie, Polska / / The Bronislaw Czech University School of Physical Education, Cracow, Poland ORCID: 0000-0001-9553-4790

\section{Państwa zaborcze wobec zbiegów i dezerterów - rosyjsko-pruskie konwencje kartelowe z lat 1816-1830}

\author{
How Invading Countries Dealt With Fugitives and Deserters - \\ Russian-Prussian Cartel Conventions from 1816-1830
}

\begin{abstract}
Relationships between the Russian Empire (and the Kingdom of Poland) and the Kingdom of Prussia, which took place during the first fifteen years after signing the Treaty of Vienna (1815), included many so-called sensitive topics. Among them there were issues of border crossing: fleeing and desertion. In order to stop or limit people from such acts, invading countries signed a plethora of cartel agreements in the years 1816-1830. One of the first agreements was signed on $13^{\text {th }} / 25^{\text {th }}$ May 1816 that soon - on $24^{\text {th }}$ March/5 $5^{\text {th }}$ April 1817 - was extended by an additional extradition order. Another important RussianPrussian agreement was a convention (with a declaration) dated back to $17^{\text {th }} / 29^{\text {th }}$ March 1830.
\end{abstract}

\footnotetext{
Marek Rutkowski - dr hab., historyk; pracuje w Akademii Wychowania Fizycznego im. Bronisława Czecha w Krakowie, autor m.in. studium Russia's commerce and navigation treaties with England, the Netherlands and Tuscany in the 1840s (2020).
} 
The discussed agreements, which regulated the procedures for effective capture and transfer of deserters and fugitives in quite detail, were supposed to refer only to legal, not political, issues partly by definition, and by international practice. This lasted until 1830, when David d'Alopaeus and Christian Bernstorff signed a cartel agreement from March 1830, which also concerned (in the secret declaration) the possible extradition of political criminals. Signing of such a convention just eights months before the outbreak of the November Uprising shows invading countries' attitude towards a possible and anticipated fight for Polish national liberation.

Keywords: extradition, cartel agreements, Russia, Prussia, nineteenth century.

\section{Wstęp}

Nowe rozwiązania prawno-państwowe wprowadzone i zatwierdzone przez Kongres Wiedeński poprzez ustabilizowanie ogólnej sytuacji polityczno-prawnej dawały podstawę do uzgodnienia szeregu kwestii wrażliwych, jakie mogły pojawiać się pomiędzy Cesarstwem Rosyjskim (i Królestwem Polskim) oraz Królestwem Pruskim. Do zagadnień takich bez wątpienia należała ciągle aktualna kwestia nadgranicznych dezercji lub zbiegostwa, generowanych czy to przez uciekających żołnierzy z Armii Czynnej, czy też tylko uskutecznianych przez rekrutów (lub osoby pozostające ,pod groźbą” ponownego powołania do wojska). W procesie nielegalnego przekraczania granicy brali też oczywiście udział uciekający przed wymiarem sprawiedliwości przestępcy.

Wszystkie te zagadnienia, przeciwdziałania, którym z mocy samej logiki równie mocno zależało obu państwom zaborczym, stanowiły oczywistą przyczynę zawierania pomiędzy Rosją i Prusami w przekroju lat 1816-1830 szeregu umów kartelowych, mających jeśli już nie zlikwidować, to przynajmniej znacznie ograniczyć dezercję i zbiegostwo. Niniejszy artykuł szczegółowo analizuje takie rosyjsko-pruskie akty prawne jak: a) umowę kartelową z 13/25 maja 1816 roku; b) tzw. dodatkowe porozumienie ekstradycyjne z 24 marca / 5 kwietnia 1817 roku; c) konwencję oraz deklarację z 17/29 marca 1830 roku. Przepro- 
wadzona analiza treści tych porozumień zawartych pomiędzy stroną rosyjską (polską) i pruską, jakkolwiek niejednokrotnie prowadząca do faktycznej rekapitulacji uprzednio już przedstawionych danych, winna tym samym umożliwić uzyskanie dokładnego obrazu możliwego ,uszczelniania” rozwiązań prawnych, mających na celu skuteczne wychwytywanie i przekazywanie wzajemne dezerterów i zbiegów. Problematyka ekstradycji realizowanej w przeszłości doczekała się bardzo wielu ważkich analiz. Dla przykładu można tu wskazać materiały autorstwa: Paula Bernarda Traité théorique et pratique de l'extradition comprenant l'exposition d'un projet de loi universelle sur l'extradition ${ }^{1}$, Christophera L. Blakesle'a The Practice of Extradition from Antiquity to Modern France and the United States: A Brief History2; Valerie C. Eppsa The Development of the Conceptual Frame Work Supporting International Extradition ${ }^{3}$, Williama Magnusona The Domestic Politics of International Extradition ${ }^{4}$.

W kwestii stosunku władz pruskich z epoki do zagadnienia ekstradycji warto polecić pracę K. A. von Kamptz'a Bruchstücke über das Recht eines Staates die gegen ihn in Auslande von einem Ausländer begangenen Verbrechen zu bestrafen ${ }^{5}$.

Na uwagę zasługuje artykuł Prusso-Russian Extradition Treaties, zamieszczony w „The New York Times”, dotyczący zasadniczo relacji ekstradycyjnych pomiędzy państwami zaborczymi, z tym, że w tym wypadku chodzi o umowę prusko-rosyjską z okresu początków powstania styczniowego ${ }^{6}$. Do nieco póź-

1 P. Bernard, Traité théorique et pratique de l'extradition comprenant l'exposition d'un projet de loi universelle sur l'extradition, Paris 1883.

2 Ch. L. Blakesle, The Practice of Extradition from Antiquity to Modern France and the United States: A Brief History [in:] 4,1, "Boston College International and Comparative Law Review" 1981, p. 39-60.

3 V. C. Epps, The Development of the Conceptual Frame Work Supporting International Extradition [in:] 25,3 "Loyola of Los Angeles International and Comparative Law Review" 2003, p. 369-388.

4 W. Magnuson, The Domestic Politics of International Extradition, [in:] 52, "Virginia Journal of International Law" 2012, p. 839-901.

5 K. A. von Kamptz, Bruchstücke über das Recht eines Staates die gegen ihn in Auslande von einem Ausländer begangenen Verbrechen zu bestrafen, [in:] 24 "Jahrbücher für preussische Gesetzgebsung Rechtswissenschaft und rechtsverwaltung", Berlin 1824, p. 19 i n.

6 Prusso-Russian Extradition Treaties, "The New York Times", May 10, 1863, p 4, [online version]: https://www.nytimes.com/1863/05/10/archives/prussorussian-extradition-treaties.html [dostęp: 4 października 2020 roku]. 
niejszego okresu odnosić się będzie tekst Hugo Keyssnera De l'extradition pour crimes soi-disant politiques, d'apres le nouveou traite conclu entre la Prusse at la Russe ${ }^{7}$, a także praca E. Ja. Schostaka $O$ vydace prestupnikov po dogovoram Rossii s innostrannymi derzavami ${ }^{8}$. Można też wspomnieć o opracowaniu: Andrée Wiessa Les crimes de delit politiques dans les rapports de l'Autriche-Hongrie et de la Russie9.

W polskiej literaturze przedmiotu wypada przede wszystkim zwrócić uwagę na pracę Gustawa Roszkowskiego $O$ azylach $i$ ekstradycji ze szczególnem uwzględnieniem austro-wegierskiej monarchii ${ }^{10}$ oraz na jego tekst $\mathrm{z}$ roku 1888: Quelques mots sur la procedurę de l'extradition ${ }^{11}$, jak też monografię Krzysztofa Latawca Rosyjska straż graniczna w Królestwie Polskim w latach $1851-1914^{12}$.

W artykule wykorzystano przede wszystkim materiały źródłowe, zamieszczane w fundamentalnej pracy F. de Martens'a Recueil des traits et conventions conclus par la Russie avec les puissances etrangers, „Dzienniku Praw Królestwa Polskiego", a także informacje o charakterze biograficznym.

\section{Umowa kartelowa rosyjsko-pruska z 13/25 maja 1816 roku}

W roku 1816 Aleksander I (tytułujący się już nie tylko cesarzem wszystkiej Rusi, ale i królem Polski) wraz z królem Prus Fryderykiem Wilhelmem III postanowili wprowadzić pomiędzy podległymi im krajami porozumienie kartelowe w sprawie ekstradycji. Obaj władcy byli bowiem „(...) ożywieni równym pra-

7 H. Keyssner, De l'extradition pour crimes soi-disant politiques, d'apres le nouveou traite conclu entre la Prusse at la Russe [in:] "Journal du droit international prive" 1885 p. 17 i n. Kiev 1883.

8 E. Ja. Schostak, O vydace prestupnikov po dogovoram Rossii s innostrannymi derzavami,

9 A. Wiess, Les crimes de delit politiques dans les rapports de l'Autriche-Hongrie et de la Russie, [in:] "Journal du droit international privé", Paris 1883, p. 247 i n.

10 G. Roszkowski, O azylach i ekstradycji ze szczególnem uwzględnieniem austro-węgierskiej monarchii, Warszawa 1882.

11 G. Roszkowski, Quelques mots sur la procedure de l'extradition, [in:] 20 "Revue de droit international", Bruxelles 1888, p. 54 n.

12 K. Latawiec, Rosyjska straż graniczna w Królestwie Polskim w latach 1851-1914, Lublin 2014. 
gnieniem, by dać sobie wzajemne dowody bliskiej przyjaźni, która ich łączy" i zastosować środki, które położyłyby „kres nadużyciom”, które z kolei prowadziły do (ułatwienia) dezercji z ich armii. Stąd ustanowiono pełnomocników obu stron do przeprowadzenia stosownych konsultacji. Ze strony Aleksandra I był to radca prywatny, szambelan, rosyjski poseł nadzwyczajny i minister pełnomocny przy dworze berlińskim - David Maksimovitsch d'Alopaeus ${ }^{13}$, kawaler orderów św. Aleksandra Newskiego i św. Anny pierwszej klasy, wielkiego krzyża orderu św. Włodzimierza drugiej klasy, oraz kawaler wielkiego krzyża orderu królewskiego Legionu Honoru (w wersji francuskiej: ,grand-cordon de l'ordre royal de la Legion d'Honneur": w wersji rosyjskiej: „королевскаго ордена почетнаго лепона болшаго креста кавалера"). Króla Prus reprezentował zaś radca stanu, Karl August hrabia (od 3 czerwca 1814 roku książę) von Hardenberg ${ }^{14}$, kawaler wielkiego orderu Czarnego Orła i Czerwonego Orła, św. Jana Jerozolimskiego, pruskiego żelaznego krzyża i krzyża św. Andrzeja etc. ${ }^{15}$

To właśnie Alepaeus i Hardenberg, wymieniwszy swoje uprawnienia, uzgodnili poszczególne artykuły ustawy kartelowej. Było zatem oczywiste, iż po opracowaniu całości treści umowy kartelowej, również ci dwaj przedstawiciele dyplomatyczni podpisali jej uzgodnione wersje finalnie, co nastąpiło dnia 13/25 maja 1816 roku. Założeniem było dokonanie wymiany ratyfikacji tejże konwencji w Berlinie w ciągu sześciu tygodni od jej podpisania, co miało jednak nastąpić jedynie ,jeśli się to uda”. Ze strony rosyjskiej umowa została następnie ratyfikowana dnia 27 lipca / 8 sierpnia 1816 roku. Porozumienie to podpisano na dwanaście lat ${ }^{16}$.

13 Alopeus graf David Maksimovitsch, [in:] Enciklopedideckij Leksikon, t. 2, Alm-Ara, Sankpetersburg: Tipografia A. Ljushara, 1835, s. 11-12, [w:] https://books.google.pl/books?id=FLcaAAAAYAAJ \&pg $=$ PA491\&hl=pl\&source $=$ gbs_selected_pages\&cad $=3 \# \mathrm{v}=$ onepage $\& \mathrm{q} \& \mathrm{f}=$ false; David Maksimovitsch Alopeus 14.12.1769 - 13.06.1831, [in:] http://www.rusdiplomats.narod.ru/ alopeus-dm.html [dostęp: 22 marca 2020 roku].

14 Hardenberg (Karol August ksiaż̇e de), [w:] Dykcyonarz biograficzno-historyczny, czyli, krótkie wspomnienia ludzi wsławionych cnota, nauka przemystem, męstwem, wynalazkami, błędami, od początku świata do najnowszych czasów, t. 1, Warszawa: Gustaw Leon Gluckberg, 1844, s. 514; H. Haussherr, W. Bußmann Hardenberg, Carl August Fürst von (preußischer Fürst 3.6.1814), [in:] 7 Neue Deutsche Biographie, 1966. [online version:] https:/www.deutsche-biographie.de/ gnd118545906.html\#ndbcontent [dostęp: 22 marca 2020 roku].

15 F. de Martens, Recueil des traits et conventions conclus par la Russie avec les puissances etrangers, t. 7, Traites avec l'Allemagne, St. Petersbourg 1855, s. 227.

16 Dziennik Praw Królestwa Polskiego, t. 6, Warszawa [1820], s. 125-127. 
Zgodnie z zapisem art. 24. umowy, treść konwencji - po wymianie ratyfikacji - przewidziano przekazać do publikacji w Cesarstwie Rosyjskim (oraz w Królestwie Polskim) i Królestwie Prus, jak też „w odpowiednich armiach”, podlegających obu władcom. Celem było doprowadzenie do sytuacji, „[...] aby nikt nie zignorował treści [porozumienia kartelowego]”, i postępował zgodnie z zawartymi w umowie (i we wszystkich jej artykułach) rozwiązaniami. Stąd przede wszystkim o postanowieniach rzeczonej umowy kartelowej zostali na wstępie poinformowani ci, którzy w dalszej kolejności mieli nowe ustalenia prawne rozpowszechniać, jak to: a) gubernatorzy i dowódcy wojskowi rosyjskich (polskich) i pruskich prowincji granicznych; b) generałowie i inni oficerowie amii; c) stosowne władze wojskowe i cywilne; d) (lokalne) rządy i ich podwładni (urzędnicy). Wskazane wyżej osoby czy urzędy obarczono zarazem nakazem ,[...] pilnowania jej [umowy - M. R.] wiernego wykonania i nadania jej w tym celu największej reklamy w swoich rządach i prowincjach, którym powierzono ich nadzór [...]". To założenie z kolei należało realizować, zamieszczając treść porozumienia kartelowego w: a) periodycznych publikacjach rocznych; b) w gazetach wychodzących w stolicach prowincji; c) w „oficjalnych wiadomościach” (jak dzienniki urzędowe etc.), redagowanych w poszczególnych prowincjach ${ }^{17}$.

Prusko-rosyjska umowa kartelowa z 13/25 maja 1816 roku zaznaczała w swoich początkowych ustaleniach, iż w momencie podpisania umowy miały być przekazane do nadgranicznych władz wojskowych i cywilnych rozkazy nakazujące „zwracać” wszystkich dezerterów opuszczających armie obu władców. Po zatrzymaniu przez stronę, do której uciekli, musieli oni być aresztowani i „zwróceni” wraz z końmi, siodłami, bronią, odzieżą i innymi rzeczami, które mieliby ze sobą czy na sobie.

Jak wynikało z dalszej części art. 1. umowy kartelowej, postanowienie to rozciągało się na armię Królestwa Polskiego, do której miały też zastosowanie wszystkie artykuły niniejszej konwencji. Z kolei do osób będących na pruskiej służbie wojskowej, których aresztowanie i „restytucję” przewidywano w rzeczonym art. 1. konwencji, zaliczono także wszystkich należących do pierwszego i drugiego zaciągu (Aufgebot) Landwehry (tj. osobników

17 F. de Martens, Recueil des traits..., t. 7, s. 240-241. 
W wieku 26-39 lat) ${ }^{18}$ zarówno oficerów, jak podoficerów i żołnierzy poruszających się pieszo lub konno.

Ustawa zarazem zastrzegła, że gdyby w przyszłości cesarz i król (co odnosiło się oczywiście do Aleksandra I) uznał za właściwe powołanie tego rodzaju wojsk (tj. podobnych w swoim charakterze do pruskiej Landwehry) w prowincjach Rosji lub Polski, to wojskowi, którzy wchodziliby w ich skład, zostaliby uznani - podobnie jak pruska Landwehra - za objętych przepisami wskazanej tu umowy.

Natomiast aresztowania i „restytucja” (wydawanie) zbiegów nie mogły być zastosowane wobec osób (tj. „tubylców”), które pochodziły z jakiejkolwiek prowincji należącej do danego państwa, do którego zdezerterowali/nielegalnie się udali, i którzy w związku z tym jedynie powracali nieformalnie do ojczyzny. Z tym, że ich konie, a także siodła, broń, ubrania i inne posiadanie przez nich rzeczy, które zabraliby ze sobą, lub które nosili przy sobie w chwili zatrzymania musiały być zwrócone temu państwu, z którego uciekli19.

Osoby pochodzące z prowincji (byłego już podczas podpisywania umowy kartelowej z roku 1816) Księstwa Warszawskiego, które znajdowały się na dany moment $\mathrm{w}$ jednej $\mathrm{z}$ armii umawiających się stron, miały zostać wzajemnie przekazane armii tego państwa, w którego granicach - zgodnie z postanowieniami traktatu z 21 kwietnia / 3 maja 1815 - znajdowało się ich miejsce urodzenia. Uzgodnienie to pozostawało jednak bezskuteczne wobec braku wyrażenia takiej woli przez samych zainteresowanych. Co więcej, wszyscy oficerowie i żołnierze, którzy w momencie podpisania rosyjsko-pruskiej konwencji kartelowej z 1816 roku znajdowali się w szeregach armii jednej ze stron porozumienia, mieli pełną swobodę pozostania w danej armii, bez obawy o jakiekolwiek reperkusje, nawet jeśliby miejsce ich urodzenia było położone na terytorium strony przeciwnej.

Osoby będące poddanymi co najmniej dwu państw, które zarazem złożyły oświadczenie o swoim deklarowanym stałym miejscu zamieszkania, i które zgodnie z treścią art. 2 traktatu wiedeńskiego z 21 kwietnia / 3 maja 1815 roku

18 W. Sonthofen, Der Deutsche Orden. 800 Jahre Geschichte, Augsburg: Weltbild Verlag 1995, s. 118 i n.; R. Bräuner, Geschichte der preußischen Landwehr. Historische Darstellung und Beleuchtung ihrer Vorgeschichte, Errichtung und späteren Organisation, Berlin 1863, s. 23 i n.

19 F. de Martens, Recueil des traits...., t. 7, s. 227-228. 
- w sposób wyraźny lub „innym jakim sposobem” (tj. milcząco) „przypisały się" niejako do konkretnego poddaństwa, i które zarazem wstąpiły do wojska jednej ze stron umowy kartelowej albo w drodze dobrowolnego zaciągu, albo też ,z skutku innych obowiązków”, traciły tym samym istotny przywilej wskazany we wzmiankowanym traktacie wiedeńskim, a dokładnie w jego art. 12. Chodziło tu zaś o przewidzianą w ciągu ośmiu lat, licząc od dnia ratyfikacji wspomnianego traktatu, możliwość dokonania dowolnego wyboru innego poddaństwa (w tekście francuskim: „un autre Souverain”). Przywilej ten można jednak było zachować pod warunkiem uzyskania rezygnacji z podjętej służby wojskowej przed upływem wspomnianego powyżej ośmioletniego okresu czasu.

Przewidziano też $\mathrm{w}$ analizowanej umowie kartelowej sytuację potencjalnego dezertera, który jeszcze przed ucieczką ze służby wojskowej pruskiej czy rosyjskiej uprzednio już opuścił wojska innego/trzeciego państwa, z którym Prusy czy Rosja zawarły umowę ekstradycyjną, Art. 5. umowy z 13/25 maja 1816 roku zalecał w takiej sytuacji powrót dezertera do tej armii, którą on porzucił w ostatniej kolejności ${ }^{20}$.

Umowa kartelowa z maja roku 1816 zdecydowanie zabraniała przy tym rekrutacji lub przyjmowania dezerterów z drugiego państwa-strony kartelu przez jakichkolwiek generałów i oficerów, oraz ogólnie przez wszystkie władze wojskowe i cywilne. Stąd było logicznym wnioskiem nałożenie na „rekruterów” obowiązku dokładnego przebadania zgłaszających się do wojska ochotników. W wypadku uznania ich za możliwych dezerterów, a to na podstawie: a) ich odpowiedzi; b) wyglądu i ,oznak” ich ubrania; c) posiadanej broni; d) innych „oznak”, trzeba było „natychmiast i nie czekając wezwania” poddać ich „procedurze zatrzymania”. Podobnie należało podstąpić wobec przyjeżdżających osób, które nie domagały się zaciągu do armii, jeśli tylko mogło się okazać, że nie były one w stanie okazać ważnego paszportu, czy przynajmniej jakiegokolwiek innego dokumentu, formalnie zwalniającego je z uprzednio odbytej służby wojskowej. Wkrótce po aresztowaniu takich właśnie osobników trzeba było zawiadomić szefa najbliższego garnizonu wojskowego, ewentualnie wobec braku organu wojskowego znajdującego się w najbliższym sąsiedztwie, takie zawiadomienie kierowano do najbliższego organu administracji cywilnej.

20 F. de Martens, Recueil des traits..., t. 7, s. 229-230. 
Celem było doporowadzenie zbiega do granicy oddzielającej oba państwastrony umowy kartelowej, gdzie należało go wydać/przekazać tym wojskowym/administratorom, którzy byliby odpowiedzialni za jego przyjęcie.

W przypadku, gdy dezerter był w stanie ukryć się przed władzami wojskowymi i cywilnymi kraju, do którego uciekł, jego poszukiwanie, aresztowanie oraz wydanie musiały być przeprowadzone przez władze „kraju schronienia”. Wszelkie poszukiwania trzeba jednak było przeprowadzić zgodnie z treścią art. 6. opisywanej tu konwencji, czyniąc tak „na pierwsze żądanie”, wyartykułowane przez władze wojskowe lub cywilne państwa, z którego terytorium dezerter zbiegł. Jednakowoż takie żądanie poszukiwania i wydania uciekiniera powinno być przedłożone najpóźniej w ciągu dwóch lat, licząc od dnia dezercji. Z wprowadzonych bowiem w maju roku 1816 przepisów wynikało jasno, iż po upływie 24 miesięcy od ucieczki dezerter nie mógł już być przedmiotem dochodzenia poszukiwawczego.

Samo wezwanie o poszukiwanie i wydanie zbiega można było złożyć do najbliższej placówki władz wojskowych czy organu administracji cywilnej strony przeciwnej. Władze wojskowe miały ustawowy obowiązek zwrócenia tych dezerterów, którzy zgłosili się do zaciągnięcia się w szeregi armii, a przedstawiciele administracji cywilnej tych uciekinierów, którzy nie stawili się w kraju ucieczki w tym celu ${ }^{21}$. Wprowadzono przy tym ogólne założenie, iż zarówno strona rosyjska, jak i pruska, miały dążyć do tego, aby wyżej wymienione wymagania zostały spełnione „szybko i uczciwie”. Aby „zwrot” dezerterów mógł odbyć się rzetelnie, według ściśle ustalonych reguł, po obu stronach granicy postanowiono wyznaczyć określone garnizony lub „miejsca pograniczne", gdzie zaplanowano przyszłe dostarczanie i wydawanie dezerterów. Do takich punktów wymiany dostarczano tych uciekinierów, którzy zostaliby złapani i przetrzymywani w relatywnie bliskiej okolicy.

Jeżeli istniały jakiekolwiek przesłanki do powstania wątpliwości co do dokładności czy rzetelności faktów określonych w roszczeniu ekstradycyjnym, nie można generalnie było ich wykorzystać do uzasadnienia odmowy zwrotu uciekiniera. Jedynym wyjątkiem teoretycznie usprawiedliwiającym takie postępowanie byłaby sytuacja, w której dezerter twierdziłby, że należy

21 Jak wynikało z umowy kartelowej, pruskie władze cywilne przyjmowały w tym zakresie polecenia i rozkazy ze strony urzędów regencyjnych. 
do państwa (byłby tamże poddanym), w którym się schronił. Wówczas trzeba było przede wszystkim ustalić stan faktyczny. Aby zapobiec pojawieniu się jakichkolwiek błędów przy ustalaniu faktycznej tożsamości takiego dezertera, władze cywilne czy też wojskowe miały obowiązek opracowania i spisania protokołów (tzw. „wywodów słownych”), które niejako dołączano do akt wydawanej osoby danego dezertera. Kopie sporządzonych protokołów trzeba było wysyłać i do władz pruskich i do władz rosyjskich ${ }^{22}$.

Istniała $\mathrm{w}$ relacjach prusko-rosyjskich generalna zasada, że odpowiednie władze wojskowe lub cywilne, czy to w miastach, czy na wsi, nie mogły zezwolić na przejazd żadnego obcego podoficera lub żołnierza lub jakiegokolwiek korpusu obcych wojsk. Wyjątkiem była sytuacja, gdy przechodzący granicę wojskowi posiadali ważne paszporty, lub „zwolnienia ze służby”. Stosowne dokumenty musiały być podpisane przez dowódcę lub osobę zarządzającą pułkiem, batalionem lub kompanią, w których przekraczający linię graniczną mieli (uprzednio) służyć. Każda osoba nie posiadająca paszportu lub zwolnienia ze służby wojskowej podlegała zatem z mocy prawa aresztowaniu i osadzeniu w „bezpiecznym miejscu”. Podobnie wypadało zatrzymać uciekiniera, znajdując przy przekraczającym bez stosownych dokumentów osobniku: a) odzież; b) broń; c) konia etc., oraz wszelkie przedmioty ruchome, zabrane przez domniemanego dezertera. $\mathrm{O}$ zatrzymaniu podejrzanego należało natychmiast powiadomić lokalne władze wojskowe lub cywilne i dalej postępować zgodnie ze standardowymi zasadami konwencji kartelowej z 13/25 maja 1816 roku.

Powyższe uzgodnienia miały - zgodnie z właśnie analizowaną konwencją - stanowić solidną podstawę do ciągłego wydawania dezerterów. Stąd uznawano w artykule 11-tym tejże umowy zapis stwierdzający, iż odtąd oba państwa będą się starać nie dopuszczać do naruszania wzajemnych granic, przy surowym zabronieniu czynów tego rodzaju. Jednocześnie po raz kolejny solennie zakazywano jakiegokolwiek zaciągania do służby wojskowej „zbiegów i poddanych drugiej strony".

$\mathrm{Ci}$, którzy naruszyliby terytorium jednego lub drugiego $\mathrm{z}$ umawiających się państw, w wypadku jeśli zostaliby przejęci w kraju, gdzie dokonali naruszenia prawa, musieli zostać ukarani na miejscu, zgodnie z prawem obowiązującym na danym obszarze. Ale jeśli uciekając uniknęliby ukarania, po 
ewentualnym przekroczeniu granicy mieli zostać jednak poddani stosownej karze w kraju „swego władcy”, zgodnie z tam obowiązującymi przepisami. W przypadku pojawienia się jakichkolwiek wątpliwości co do ustalenia rodzaju popełnionego czynu karalnego, czy też jakichś „,szczególnych okoliczności”, musiała teraz być powołana specjalna komisja dwustronna, której przewodniczyli komisarze strony poszkodowanej. Wyrok tej komisji, potwierdzony przez władze dwu państw, trzeba było jak najszybciej wykonać23.

Koszty utrzymania złapanego, popełniającego zbrodnie czy wykroczenia dezertera określono pierwotnie w treści artykułu 16 konwencji kartelowej z 25 maja 1816 roku. Otóż licząc od dnia aresztowania przestępcy lub oskarżonego, trzeba było wypłacać dziennie na jego utrzymanie kwotę rzędu 1,5 polskiego złp (w tekście francuskim mowa oczywiście o florenach); do tego dochodziło kolejne dwa złote (floreny) wypłacane na pokrycie kosztów jego pobytu $\mathrm{w}$ areszcie. Kwoty te wypadało zwrócić podczas procesu przekazania danego skazanego kryminalisty lub tylko oskarżonego; cały proces zwrotu gotówki zaś miał być - w miarę możliwości - przyśpieszony ${ }^{24}$.

Umowa regulowała też warunki utrzymania złapanego konia dezertera, na co przeznaczano dwa garnce owsa, a także osiem funtów siana dziennie wraz ze słomą. Furaż dla zwierząt musiał być opłacany według stawek, które zostałyby każdorazowo podane według ceny rynkowej, obowiązującej w najbliższym mieście. Pełna opłata tych kosztów następowała dopiero po oddaniu dezertera $\mathrm{i}$ jego konia; przy czym kwoty te w żadnym wypadku nie mogły zostać w międzyczasie zwiększone.

Celem nadania temu zarządzeniu klauzuli pełnej „skuteczności” (wykonalności), obie strony umowy zobowiązały się w maju roku 1816 do zdeponowania określonej sumy pieniędzy w biurach władz, powołanych (na mocy artykułu 8. konwencji) w garnizonach lub granicznych punktach wymiany, ustanowionych w celu przyjmowania dezerterów. Koszty utrzymania, a także wynagrodzenie za wiadomości o podejrzanych, czy nawet za dostarczenie uciekinierów, trzeba było bezpośrednio i „bez żadnej trudności” (w tekście francuskim: sans aucune difficulte) opłacić w formie rachunku, który miał być przedstawiony przez organ publiczny odpowiedzialny za zwrot dezertera, jed- 
nocześnie z wydaniem schwytanego uciekiniera. Jeśliby okazało się, iż rachunek był sporządzony wadliwie (co jednak - jak podawała treść konwencji oczywiście nie powinno mieć miejsca, przy założeniu dokładnego określenia wszelkich stawek, kosztów utrzymania i wynagrodzeń), przedłożone roszczenia nie nadawały się do rozpatrzenia, dopóki pełna płatność nie zostałaby czasowo przynajmniej dokonana. Ponieważ zbiedzy nie mogli formalnie zaciągać długów, państwo przyjmujące dezertera (l'etat requerant) nie mogło domagać się spłaty takich zobowiązań. Uznano też, iż po aresztowaniu zbiega jego wydanie musiało nastąpić nie później niż osiem dni po fakcie zatrzymania, które z kolei powinno było nastąpić natychmiast po jego wyśledzeniu ${ }^{25}$.

Było oczywistym, że nagrodę pieniężną przyznawano ze strony kraju, do którego zwracano dezertera, temu, kto doniósł o miejscu przebywania danego zbiega czy wręcz go doprowadził do siedziby władz wojskowych lub cywilnych. Wysokość wynagrodzenia została określona na „półtora dukata holenderskiego” od każdego pieszego mężczyzny oraz „dwa i pół dukata” dla jeźdźca z koniem.

Jednocześnie wprowadzono zasadę, na mocy której osoby, które: a) na terenie podległym królowi pruskiemu lub carowi rosyjskiemu dopuściłyby się jakiegokolwiek przestępstwa o charakterze kryminalnym; b) byłyby oskarżone o popełnienie czynu zabronionego, a następnie uciekły, udając się na teren podległy władzy drugiego ze wzmiankowanych suwerenów, po ewentualnym złapaniu zostałyby następnie wydane ,za pierwszym wezwaniem”. Owe natychmiastowe przekazanie przeprowadzano niezależnie od „stanu” i pozycji społecznej przestępcy/oskarżonego, niezależnie od tego, czy pochodził on ze szlachty, mieszczan, chłopów, czy też podlegał pod kategorię tzw. „wolnych poddanych"; czy był on osobą wojskową czy też cywilną.

Jeśli wspomniany kryminalista lub oskarżony okazał się być poddanym monarchy, gdzie szukał on jako dezerter/uciekinier schronienia, popełniwszy czyn zabroniony w kraju - drugim partnerze umowy kartelowej, w takiej sytuacji (zgodnie z treścią art. 14. umowy) nie należało go wydawać. Z drugiej strony władze kraju, do którego jako do swojej ojczyzny taki podsądny uciekł, miały obowiązek wymierzenia mu „spiesznej i ścisłej sprawiedliwości”. Jeżeli jednak jakakolwiek osoba została aresztowana w kraju, w którym popełniła 
przestępstwo lub wykroczenie, wówczas władze administracyjne czy wojskowe państwa, w którym nastąpiło aresztowanie, posiadały uprawnienia do wymierzenia takiemu osobnikowi stosownej kary, nawet gdy taka osoba podlegałaby formalnie władcy drugiego państwa - strony umowy kartelowej.

Wnioski o wydanie dezerterów trzeba było kierować do władz relatywnie wysokiego szczebla, mianowicie do ,gubernatorów wojskowych i cywilnych” cesarza Rosji i króla Polski, oraz do regencji Królestwa Prus, „[...] nie zaś do władz i sądów niższego szczebla". W konsekwencji organ, do którego się zwracano (o ile tylko posiadał takie uprawnienia), miał za zadanie wydanie polecenia o odstawieniu zbiega. W praktyce miało to polegać na tym, iż strona wezwana wskazywała jednostkę wojskową odpowiedzialną za odprowadzenie dezertera do granicy, gdzie poszukiwana osoba była przekazywana osobom powołanym przez stronę upoważnioną do przejęcia uciekiniera. Nowe prawo wskazywało zarazem, iż jeżeli z dowolnego powodu można było zakwalifikować daną osobę jako podlegającą wydaniu stronie przeciwnej (a mianowicie zgodnie z zasadami określonymi w artykule 14 . konwencji), powinna ona być wydana niejako automatycznie, tj. nawet bez formalnego wniosku w tej sprawie. Poprzedzające takie wydanie aresztowanie następowało na polecenie odpowiednich władz wojskowych i cywilnych. Na dalszym etapie procedury przekazywano przedstawicielom kraju strony drugiej stosowne informacje o takim zatrzymaniu i gotowości do „Zwrotu” uciekiniera ${ }^{26}$.

Nie wolno było ścigać dezertera, skazanego kryminalisty lub osoby oskarżonej na terytorium państwa, do którego tenże osobnik zbiegł poprzez stosowne organy kraju żądającego jego wydania. Nie można było tego robić: a) ani w drodze jawnej przemocy (poprzez najazd na terytorium strony drugiej); b) ani przez inne działania o charakterze samowolnym; c) ani też potajemnie. $Z$ tego powodu wyraźnie zabroniono przekraczania granicy obu państw przez jakiekolwiek oddziały wojskowe lub grupy cywilne, a nawet możliwości takiej zostali pozbawieni tzw. „tajni posłańcy”. Każde takie naruszenie terytorium państwa drugiego powodowało zatrzymanie, aresztowanie i ukaranie osób winnych takiego „najazdu” lub naruszenia obowiązujących w tej mierze przepisów, już w miejscu mającego miejsce wykroczenia. Jeżeli ze strony władzy, która domagałaby się zwrotu uciekiniera, nastąpiłoby formalne wydanie 
nakazu ścigania przez oddział wojskowy lub cywilny (lub też i w inny sposób) konkretnego dezertera czy większej liczby dezerterów (podobnie i jednego lub większej liczby przestępców lub oskarżonych), taki pościg nie mógł postępować dalej niż do granicy dwóch umawiających się państw - stron porozumienia. Grupa pościgowa miała zatem obowiązek zatrzymania się na samej linii granicznej, gdzie tylko jedna osoba ze ścigających mogła przekroczyć granicę. Wysłannik ten musiał się zresztą (po przekroczeniu granicy) powstrzymywać od jakiegokolwiek aktu przemocy lub okazywania jakichkolwiek „znamion” swojej władzy. Zamiast tego miał on zwrócić się do najbliższego organu wojskowego lub cywilnego państwa, na terytorium którego się znalazł, celem usankcjonowania swego pobytu i przedstawienia wymaganych listów (uwierzytelniających) od przełożonych, zawierających przede wszystkim żądanie wydania uciekiniera. Obowiązkiem strony przyjmującej było natomiast powitanie takiego wysłannika urzędu ścigającego „z należytym szacunkiem” i prowadzenie dalszego postępowania zgodnie z umową kartelową z 13/25 maja 1816 roku.

Na przedstawicielach (wojskowych i urzędnikach) obu państw ciążył obowiązek niedopuszczania do „przechowywania zbiegów”, przez co rozumiano dezerterów, kryminalistów i osoby podejrzanie o dokonanie przestępstw. Podobny zakaz dotyczył dyslokacji tych osób w odległe okolice, prowincje lub do daleko (od granicy państwowej) położonych garnizonów wojskowych w celu utrudnienia lub uniemożliwienia dochodzenia w kwestii ich wydania. Aby zresztą względnie ujednolicić postepowanie ekstradycyjne, art. 18. umowy kartelowej zakładał, iż obie strony miały opracować w miarę spójne przepisy dotyczące kar nakładanych za oskarżonych o zbliżone przestępstwa. Jednocześnie władze obu krajów zobligowane zostały do wzajemnego przekazywania informacji o karach wymierzonych za przestępstwa nawiązujące do umowy kartelowej z roku 1816. Za czynniki zapewniające adekwatność kar do skali przestępstw, ich natury i okoliczności popełnienia, miały służyć - przynajmniej według sygnatariuszy nowego porozumienia - „,interes i znane zasady obydwu rządów, tudzież prawa przez nich przyjęte" (w wersji francuskiej tekstu: L'interet et l'equite des deux gouvernements, aisi que les lois qu'ils ont adoptees).

Ustawa zapobiegała też - przynajmniej teoretycznie - podejmowaniu jakiegokolwiek handlu z uciekinierami. Mianowicie zabroniono zarówno na 
terenie podległym władzy carskiej, jak i króla pruskiego, kupowania od dezerterów wszelkich zabranych przez nich rzeczy, a w szczególności: a) koni; b) siodeł; c) ich broni; d) ich odzieży. Przy okazji niejako wprowadzono zasadę, na mocy której wszystkie przedmioty zakupione od dezerterów ich nabywcy musieli bezpłatnie zwrócić. Co więcej, nawet gdyby nabyte zwierzęta i towary (konie, siodła, broń, odzież i uzbrojenie) nie były już dłużej w posiadaniu dokonującego pierwokupu od dezertera, musiał on zwrócić równowartość ich formalnej ceny. Wreszcie kupcy nielegalnie przewiezionych przez granicę przez uciekinierów przedmiotów podlegali karze (administracyjnej) nakładanej zgodnie z prawem konkretnego państwa ${ }^{27}$.

Przewidywano też konsekwencje w razie braku odstawienia do granicy uciekającego dezertera, przestępcy czy podejrzanego według i na warunkach zamieszczonych w analizowanej konwencji. Chodziło mianowicie o opisywaną $\mathrm{w}$ artykule 20. umowy kartelowej sytuację, gdy miał miejsce powrót takiego (w drodze kolejnej już dezercji lub ucieczki) dezertera, który - wbrew postanowieniom umowy z 13/25 maja 1816 roku - zaciągnął się do armii państwa drugiego lub nawet nie został do niej przyjęty, a który później wrócił do miejsca swojej pierwotnej służby. W takich sytuacjach władze kraju, z którego pierwotnie dezerter uciekł, nie musiały go zwracać drugiej stronie.

Poruszono też w umowie kwestię włóczęgów lub wydalanych przestępców, gdzie obydwie strony porozumienia zobowiązały się przede wszystkim do zapobiegania nadgranicznemu włóczęgostwu. Poza tym postanowiono nie dopuścić do przechodzenia przez pruskie czy rosyjskie terytoria wypędzanych z drugiego kraju-sygnatariusza porozumienia kryminalistów. Oznaczało to zakaz wzajemnego wpuszczania do kraju tych dwu kategorii osób, chyba że osoby te się urodziły lub miały udokumentowane formalne miejsce swego ostatniego pobytu w danym państwie. Jednakowoż w obu tych wypadkach najbliżej zlokalizowane władze obu krajów musiały być powiadomione o mającym nastąpić wydaleniu takiego osobnika (tj. włóczęgi czy kryminalisty). Stosowne zawiadomienie powinno zawierać dokładne wskazanie lokalizacji „oddania takiego człowieka”. Podczas przekazywania wydalanego włóczęgi czy przestępcy należało zawsze okazać dokumenty potwierdzające miejsce urodzenia lub ostatnie miejsce zamieszkania osoby, która miała być wydalana. 
Przy tak opisanym przejmowaniu wydalanego włóczęgi/przestępcy nie naliczano jednak jakichkolwiek kosztów administracyjnych, ponieważ z reguły nie następowało ono na uprzednio złożony wniosek ekstradycyjny.

Dla twórców umowy kartelowej z 13/25 maja 1816 roku było oczywiste (a odzwierciedleniem tego była treść art. 22. rzeczonej ustawy), iż podpisana umowa nie miała mocy prawnej o charakterze wstecznym. Stąd wynikało, iż nie należało wydawać wszystkich zbiegów/dezerterów, którzy dopuścili się ucieczki, przed terminem ustalonym w pierwszym artykule niniejszej konwencji (tj. do momentu podpisania czy ratyfikacji raczej umowy, czyli w maju/ sierpniu 1816 roku, ale nie później niż 8 sierpnia 1816 roku), jak też i osób, co do których nie obowiązywały stosowne wyłączenia (,wyjątki”) prawne.

Jeżeli zaś chodziło o uciekających przestępców lub oskarżonych, którzy byliby przedmiotem wniosków o ekstradycję zgodnie z art. 14. umowy kartelowej, to w ich wypadku stosowano inną zasadę. Mianowicie nawet jeśli przestępstwo, którego się dopuścili, popełniono przed początkiem obowiązywania rosyjsko-pruskiej konwencji kartelowej z roku 1816, i tak należało dokonać ich ekstradycji. Poza tym przyjęto, iż wszystkie ewentualne spory, które mogły pojawić się pomiędzy Prusami i Rosją na tle dezercji i zaciągu do służby wojskowej wynikłe do czasu podpisania niniejszej konwencji, miały być zakończone czy anulowane na mocy przepisów właśnie wprowadzanej w życie umowy ${ }^{28}$.

Reasumując należy stwierdzić, że jedną z głównych cech charakterystycznych dla rosyjsko-pruskiej umowy kartelowej z 13/25 maja 1816 roku było założenie objęcia przepisami ekstradycyjnymi także uciekinierów z okresu poprzedzającego jej podpisanie. Jednak stosowne domaganie się wydania takiego uciekiniera musiało być przedłożone nie później niż w ciągu dwóch lat od dnia dezercji. Po samym zatrzymaniu zaś zbiega, teoretycznie przynajmniej, jego wydanie musiało mieć miejsce nie później niż w terminie ośmiu dni po ujęciu. Nie pozostawiający wątpliwości co do faktycznej woli prusko-rosyjskiego współdziałania w zakresie ekstradycji zbiegów był zapisany w umowie projekt rejestru możliwie jednolitych kar nakładanych na uciekinierów oskarżonych o podobne przestępstwa. Innym istotnym wyznacznikiem konwencji było zapewnienie możliwości pozostania w danej armii tym oficerom i żołnierzom, 
którzy w momencie uzgodnienia tego aktu prawnego znaleźli się w szeregach armii jednej ze stron umowy. Wreszcie całościowy tekst ustawy z maja 1816 roku był zatem - jak się wydaje - dość spójny i logiczny.

\section{Dodatkowa umowa kartelowa rosyjsko-pruska z 24 marca / 5 kwietnia 1817 roku}

W dniu 24 marca / 5 kwietnia 1817 roku w Berlinie pełnomocnicy cara Aleksandra I oraz króla pruskiego Fryderyka Wilhelma III - D’Alopaeus i Hardenberg - podpisali tzw. artykuły dodatkowe do umowy kartelowej, zawartej uprzednio pomiędzy Rosją i Prusami w dniu 13/25 maja 1816 roku. Opracowane i potwierdzone przez obie strony artykuły uzupełniające miały oczywiście taką samą moc i wartość, jak gdyby zostały pierwotnie umieszczone - słowo w słowo - w ubiegłorocznym porozumieniu kartelowym. Pociągało to za sobą automatycznie niejako konieczność ich pełnej implikacji przez władze obu stron porozumienia. Po dołączeniu do uprzedniej konwencji, miały te nowe przepisy zostać dodatkowo ratyfikowane (samą wymianę ratyfikacji umowy planowano doprowadzić do skutku w okresie 6 tygodni od podpisania lub wcześniej), co ze strony rosyjskiej faktycznie nastąpiło dnia 18 kwietnia / 1 maja 1817 roku $^{29}$.

Uzgodnienie i późniejsze umowy uzupełniające do ustawy kartelowej zasadniczo zaś były spowodowane tym, iż po ratyfikacji konwencji z 25 maja 1816 roku zarówno król pruski, jak i car rosyjski, postanowili zmienić treść zapisów uprzednio zawartych w artykułach 11., 12. i 16. rzeczonego porozumienia. W ocenie zaborców bowiem ich dalsze stosowanie mogło przyczynić się do pojawienia się szeregu nieprzewidzianych trudności, wyczerpujących możliwie nawet znamiona następstw o charakterze przeciwskutecznym. Stąd, mając na uwadze powyższe założenia, zarówno D’Alopaeus, jak i Hardenberg, uzgodnili szereg nowych rozwiązań prawnych, skupiając się przede wszystkim na procedurze dochodzenia $\mathrm{w}$ sprawie przestępstw związanych z naruszeniem terytorium oraz z ustaleniem kosztów utrzymania dezerterów ${ }^{30}$.

30 Tamże, s. 131-133. 
Zastępujące uprzednioroczne rozwiązania prawne nowe przepisy były zatem następujące. Po pierwsze (zgodnie z uzupełniającym artykułem 1-szym) każda osoba aresztowana w kraju, w którym dopuściła się naruszenia jego terytorium, miała zostać postawiona przed sądem wojennym tego konkretnego państwa, położonym najbliżej miejsca przestępstwa. To na tym sądzie spoczywał obowiązek: a) zbadania okoliczności sprawy; b) wysłucha świadków; c) uporządkowania akt do tego stopnia, aby można było na ich podstawie wydać finalny wyrok. Akta te w dalszej kolejności należało przesłać do naczelnego dowódcy wojska (w wersji francuskiej: general en chef des troupes), do szeregów którego należał podsądny, celem wydania wyroku, co następowało oczywiście (przynajmniej w teorii) zgodnie z prawem danego kraju. Kolejnym etapem tej nowej procedury było przekazanie wyroku do sądu uprzednio przesyłającego akta. Tu następowało teraz ogłoszenie sentencji wyroku osobie oskarżonej, która przebywała do tego momentu w lokalnym areszcie. W zależności od treści nadesłanego ze strony naczelnego dowództwa wojskowego wyroku, pozwany zostawał albo natychmiast zwolniony, albo wydany najbliższemu organowi wojskowemu/administracyjnemu drugiego państwa, w celu nałożenia na niego kary ${ }^{31}$.

Jak dowiadywaliśmy się z artykułu 3. uzupełnień, samo śledztwo dotyczące możliwej ekstradycji musiało być prowadzone „ciągle”, bez żadnych przerw czy zakłóceń, oraz powinno być przeprowadzone w miarę możliwości pośpiesznie. Gdyby organ właściwy do wydania wyroku żądał jakiś dodatkowych wyjaśnień, takie informacje musiały być dostarczone na wniosek tego organu przez władze wojskowe/administracyjne bezpośrednio zaangażowane w śledztwo w danej sprawie.

Dodatkowo w kwietniu roku 1817 poruszono jeszcze kwestię kosztów utrzymania przetrzymywanych $\mathrm{w}$ areszcie dezerterów. W efekcie zamiast ceny ustalonej w artykule 12. umowy kartelowej z 13/25 maja 1816 roku uzgodniono teraz, iż koszty utrzymania każdego złapanego uciekiniera będą opłacone według stawki dwóch „dobrych groszy pruskich”, czyli piętnastu groszy polskich. Pozostałe ustalenia pozostawały takie, jak je określono we wspomnianym artykule.

31 F. de Martens, Recueil des traits, t. 7, s. 245. 
Zmieniając również postanowienia zawarte w treści artykułu 16. rosyjsko-pruskiego porozumienia kartelowego z 1816 roku, ustalono, iż od dnia aresztowania nielegalnie przekraczającego granicę przestępcy lub oskarżonego (zakwalifikowanego do tej kategorii zgodnie z artykułem 14. konwencji), począwszy od kwietnia do maja 1817 roku dzienne koszty uwięzienia takiej osoby obliczano na trzy dobre grosze pruskie, czyli dwadzieścia dwa i pół groszy polskich. Koszty te musiały być opłacone w momencie przekazania przestępcy lub oskarżonego ${ }^{32}$.

Jak widzimy, dokonane w kwietniu roku 1817 uzupełnienia konwencji kartelowej z maja roku 1816 dotyczyły zarówno kwestii prawnych, jak i administracyjnych oraz finansowych.

\section{Konwencja i deklaracja prusko-rosyjska z 17/29 marca 1830 r.}

Podpisana w dniu 13/25 maja 1816 roku umowa kartelowa pomiędzy carem Aleksandrem I oraz królem pruskim Fryderykiem Wilhelmem III w roku 1830 straciła ważność. Jednocześnie niektóre jej postanowienia zostały uznane za wymagające uzupełnienia czy też sporządzenia ich w sposób bardziej zrozumiały oraz dokładny. $\mathrm{Z}$ drugiej strony, inne z dotychczasowych rozwiązań prawnych nie odpowiadały już zmieniającej się dość gwałtownie pod koniec lat dwudziestych XIX wieku rzeczywistości. Stąd nowy car rosyjski - Mikołaj I - oraz dotychczasowy król pruski Fryderyk Wilhelm III uznali za pożyteczne i właściwe zawarcie nowej umowy kartelowej, wyznaczając naturalnie w tym celu swoich pełnomocników: a) ze strony rosyjskiej był to poseł nadzwyczajny i pełnomocnik ministra przy królu Prus David d'Alopaeus, wówczas carski prywatny doradca i szambelan ${ }^{33}$, kawaler orderu św. Aleksandra Newskiego i św. Włodzimierza pierwszego stopnia itd.; b) ze strony króla Prus - jego minister stanu, gabinetu i spraw zagranicznych Christian Günther hrabia de Bernstorff ${ }^{34}$,

32 Tamże, s. 245-246.

33 Tamże, t. 8: Traires avec l'Allemagne 1825-1888, Sankt Petersbourg 1888, s. 126.

34 H. Kellenbenz, Bernstorff, Christian Günther Graf von, [in:] 2. Neue Deutsche Biographie, Berlin, p. 139-140, https://www.deutsche-biographie.de/ppn116147695.html [dostęp: 13 listopada $2020 \mathrm{roku}]$. 
kawaler pruskich orderów Czarnego Orła i Czerwonego Orła pierwszej klasy; rosyjskiego orderu św. Andrzeja i św. Aleksandra Newskiego itp. W konsekwencji to oni obaj uzgodnili i zawarli ostatecznie wspomniane powyżej porozumienie kartelowe ${ }^{35}$. Umowę podpisano w Berlinie (Alopeus, Bernstorff) dnia 17/29 marca 1830 roku, a została ona ratyfikowana przez stronę pruską 8 kwietnia 1830 roku (z wymianą dokumentów również w Berlinie dnia 19 kwietnia / 1 maja 1830 roku). Natomiast car Mikołaj I dokonał jej ratyfikacji 19/31 sierpnia 1830 roku $^{36}$. Czas obowiązywania tej nowej umowy kartelowej określono na dwanaście lat, tj. do 30 kwietnia 1842 roku $^{37}$.

Nowa konwencja, którą zaplanowano wdrażać od daty jej ratyfikacji, z założenia miała zastosowanie: a) do wszystkich osób, które pozostając w czynnej służbie w armii Królestwa Polskiego i Cesarstwa Rosyjskiego oraz Królestwa Prus dopuściły się dezercji (jej przepisy obejmowały także zasady zwrotu uzbrojenia oraz przedmiotów „wojskowych”, które dezerterzy sprowadziliby poprzez granicę ze sobą, takich jak: konie, uprzęże, broń, czy odzież); b) do „,indywiduów”, którym przyznano urlop z wojska tylko pod warunkiem wzięcia udziału po pierwszym wezwaniu do powrotu do czynnej służby, i którzy osobnicy w związku z tym należeli do rezerwy w momencie przekroczenia granicy państwowej; c) do wszystkich osób które - zgodnie z prawem państwa, które opuściły z zamiarem ponownego wjazdu lub bez niego - podlegałyby, nawet w późniejszym okresie, służbie wojskowej38; d) do osób, które popełniły przestępstwa w jednym z dwóch państw, a następnie uciekły na terytorium drugiego, aby uniknąć ścigania i poniesienia kary.

35 F. de Martens, Recueil des traits, t. 8, s. 127.

36 G. F. de Martens, F. Saalfeld, Nuveau recueil des Traites d"Alliance, de Paix, de Treve, de Neutralitie, de Commerce, de Limites, d'Echange etc de plusieurs autres actes servant a la connoissance des relations etrangeres des puissances et etats de l'Europe tant dans leur rapport mutual que dans celui envers les puissances et etats dans d,autres parties du globe depuis 1808 jusqu'a present, T. 8, 1825-1830 incl., Gottingue 1831, s. 244, 255. Formalnie konwencja ta została tu określona jako: „Convention de cartel entre la Prusse et la Russie t de la Pologne, signe le 17/29 mars 1830”, [w:] https://books.google.pl/books?id=e4gaAQAAIAAJ\&pg=PA244\&lpg=PA244\&dq=Chretien+Gonthier + comte++de+Bernstorff\&source=bl\&ots=IciiBLwtIg\&sig=ACfU3U1Me8fAFBQuOxgbVAgVmxt5hkgmug\&hl=pl\&sa=X\&ved=2ahUKEwjuqOPhoLDoAhXykIsKHQIsC5IQ6AEwBnoECAQQAQ\#v=onepage\&q=Chretien $\% 20$ Gonthier $\% 20$ comte $\% 20 \% 20 \mathrm{de} \% 20$ Bernstorff\&f=false [dostęp: 11 sierpnia 2020 roku].

37 F. de Martens, Recueil des traits, t. 8, s. 144.

38 Tamże, s. 127. 
Jeżeli dezerterzy z armii czynnej: a) zostaliby ujęci w mundurze; ewentualnie: b) jeżeliby znaleziono przy nich „untensylia” (sprzęty) wojskowe; c) gdy - ogólnie rzecz ujmując - nie było żadnych wątpliwości, że w danym wypadku „zrezygnowano” z czynnej służby w armii drugiego państwa, zostałyby takie osoby „natychmiast i bez uprzedniej zgody tego [poszkodowanego] państwa" aresztowane, a następnie zabrane wraz ze stwierdzonymi przy nich przedmiotami o charakterze wojskowym na granicę oddzielającą oba kraje, gdzie trzeba je było przekazać właściwemu organowi odpowiedzialnemu za ich przyjęcie po stronie drugiej.

Kiedy dezercja złapanych osób fizycznych nie była oczywista, ale okazywała się wysoce prawdopodobną w wyniku zaistnienia specyficznych okoliczności lub tylko pojawienia się szczególnych informacji ze strony władz wojskowych lub cywilnych, które dowiedziałyby się o pobycie takiej osoby, należało niezwłocznie podjąć niezbędne środki, aby zapobiec dalszej ucieczce takiego osobnika. Następnie sporządzano na ten temat raport i przekazywano go organowi wojskowemu drugiego państwa „na szczeblu wojewódzkim”. Tutaj weryfikowano w dalszej kolejności, czy oskarżony faktycznie opuścił nielegalnie granice swego kraju. Po stwierdzeniu zaistnienia takiego faktu, złapany dezerter zostawał formalnie wydany stronie drugiej ${ }^{39}$. Osoby uprzednio urlopowane z wojska i złapane po nielegalnym przekroczeniu granicy, mogły zostać aresztowane i zwrócone stronie drugiej wyłącznie na jej wyraźny wniosek, który w każdym szczególnym przypadku musiał być złożony przez właściwy organ państwowy.

Ekstradycja wszystkich osób w jakikolwiek sposób powiązanych z czynną lub bierną służbą wojskową nie mogła jednak nastąpić: a) zanim przed wyjazdem do państwa, które opuściły jako ostatnie; lub b) zanim tam podjęły one służbę, byli ci osobnicy pierwotnie poddanymi tego państwa-strony układu, w którym się schronili po swojej ucieczce/dezercji. Działo się tak nawet jeśli wydane w ich poszukiwaniu raporty (listy gończe) nie zostały anulowane, przy zachowaniu form zwyczajowych dla danego państwa. W takim jednak wypadku należało zwrócić konie i części oporządzenia wojskowego, które osoby te zabrały ze sobą. Podobnie, jeżeli uciekająca osoba, tak czy inaczej powiązana ze służbą wojskową, okazała się winna popełnienia przestępstwa w państwie, 
do którego zdezerterowała, można było odmówić jej ekstradycji przynajmniej do czasu jej właściwego ukarania, a to zgodnie z przepisami danego kraju. Wreszcie, w przypadku, gdy aresztowanie i ekstradycja danej osoby nastąpiłaby tylko po złożeniu wniosku w tej sprawie przez stronę ,poszkodowaną”, a od czasu dezercji czy ucieczki tej osoby minęło już pięć lat, żadne z państw - stron układu ${ }^{40}$, do którego skierowana byłaby prośba o wydanie takiego uciekiniera, nie miało obowiązku realizować wskazanego roszczenia.

Komunikaty o potrzebie zatrzymania dezertera, podejrzewanego o służenie w armii państwa-strony układu musiały być wysyłane: a) przez służby Cesarstwa Rosyjskiego i Królestwa Polskiego do generała-dowódcy wojsk stacjonujących w najbliższej prowincji pruskiej; b) ze strony Prus do naczelnego wodza (armii czynnej) oraz do oficerów bezpośrednio odpowiedzialnych za ekstradycję dezerterów. Natomiast wymogi zgłaszania potrzeby ekstradycji odnoszące się do osób fizycznych - ewentualnych rezerwistów - miały być skierowane przez stronę rosyjską i polską do najbliższej regencji prowincjonalnej pruskiej; a ze strony pruskiej do najbliższych władz wojskowych i cywilnych rosyjskich czy polskich.

Gdy się zdarzyło, że dana jednostka przed wycofaniem się ze służby kraju - jednej ze stron układu opuściła wojska innego suwerena/państwa, z którym Rosja czy Prusy zawarłaby porozumienie kartelowe, taki dezerter mimo to wróciłby do wojska, które opuścił w ostatniej kolejności.

Prusko-rosyjska umowa kartelowa z roku 1830 wyraźnie zabraniała władzom obu państw angażowania w służbę wojskową lub cywilną ${ }^{41}$ osób, których dezercja z czynnej armii drugiego państwa nie budziła wątpliwości, a nawet byłaby tylko prawdopodobna. Władze wojskowe i cywilne nie mogły pozwolić na przechodzenie przez granice ani podoficerom, ani żołnierzom szeregowym armii sąsiedniego państwa, chyba że wojskowi ci posiadaliby ważne paszporty albo piśmienne pozwolenia wydane przez naczelnika lub dowódcę oddziału wojskowego/korpusu. Jakikolwiek paszport lub pisemny dokument uprawniający do przejścia linii granicznej powinien być wydany przez władze jednostki, do której przekraczający granicę formalnie należał. Gdy pojawiało się podejrzenie - na podstawie „zewnętrznych oznak” lub wobec zapoznania

40 F. de Martens, Recueil des traits, t. 8, s. 129.

41 Tamże, s. 130. 
się z innymi „okolicznościami” - że dany dokument należał/był wydany przez inne jednostki umawiających się państw, posługujący się nim osobnik musiał natychmiast być zatrzymany wraz ze wszystkimi rzeczami, które miał ze sobą, a po przesłuchaniu zostałby potraktowany zgodnie $\mathrm{z}$ treścią art. 2. konwencji kartelowej (tj. wydany państwu, z którego strony przybył).

Obie strony konwencji kartelowej zobowiązały się podjąć zadawalające środki w celu zapewnienia uczciwego i natychmiastowego rozpatrzenia, przeprowadzenia czy realizacji wszystkich wniosków otrzymanych od władz strony przeciwnej w stosunku do uciekających/dezerterujących osób, mających status jednostek urlopowanych z wojska. Gdyby nawet tacy osobnicy byli personalnie zaangażowani w służbę państwu, na którego terytorium się w danym momencie znajdowali, ta okoliczność nie mogła mieć wpływu na wzajemne zobowiązania deportacyjne ${ }^{42}$. Co więcej, gdyby nawet pojawily się jakiekolwiek wątpliwości odnośnie do ścisłości czy dokładności danych zawartych we wniosku ekstradycyjnym, takie ewentualne nieścisłości nie mogły - co do zasady, poza pewnymi wyjątkami - uzasadnić odmowy przekazania zbiega.

Wydaniu dezertera z armii czynnej czy tylko osoby podlegającej służbie wojskowej jako rezerwista lub rekrut musiało zawsze towarzyszyć sporządzenie i przekazanie drugiej stronie raportu, względnie protokołu, który należało przede wszystkim opracować w odniesieniu do przyczyn i okoliczności aresztowania. Jeżeli złapana osoba należała do tych, które zgodnie z art. 2. konwencji kartelowej z 1830 roku musiały zostać dostarczone niejako „automatycznie", wówczas jej ekwipunek - który jako taki posłużył czy tylko przyczynił się do ujawnienia zaszłej dezercji - powinien był zwrócony „,natychmiast" razem z wydalaną osobą. Z kolei, jeśli złapana jednostka należała do kategorii tych, których należało przekazać dopiero po przeprowadzeniu uprzedniej komunikacji między odpowiednimi władzami wojskowymi dwu stron (ewentualnie na skutek wystawienia formalnego aktu oskarżenia), wówczas w celu usunięcia wszelkich wątpliwości, że jej ekstradycja jest zgodna z zasadami opisywanej konwencji, protokół roszczeń, które jej dotyczyły, musiał być zawsze przedstawiony podczas ekstradycji w oryginale.

Zgodnie z art. 10. konwencji z 17/29 marca 1830 roku, punkty graniczne, ustalone do tej pory dla przeprowadzania regularnej ekstradycji dezerterów 
i innych osób wydalanych nadal miały być wykorzystywane do tego samego celu. Taka sytuacja miała trwać do momentu ewentualnego udzielenia przez obie strony konwencji zgody na jakiekolwiek zmiany terytorialne w zakresie lokalizacji punktów wymiany ${ }^{43}$. Wyznaczenie urzędników desygnowanych do przyjmowania w tych miejscach wydawanych dezerterów czy zbiegów w zależności od tego, czy urzędnicy ci należeliby do kategorii wojskowych, czy też do służby cywilnej - nastąpić miało albo za pośrednictwem właściwego organu wojskowego, albo przez organ administracji cywilnej.

W przypadku każdego dezertera $\mathrm{z}$ armii czynnej lub osoby podlegającej poborowi czy tylko konieczności pozostawania w rezerwie służby wojskowej, koszty jego utrzymania miały być obliczone według stawki piętnastu groszy polskich lub dwu pruskich groszy „kurantowych”? (w oryginale: deux gros curants) za dzień pobytu. Kwoty naliczano od dnia zatrzymania do dnia wydania, niezależnie od tego, czy następowało ono „na żądanie”, czy nie. Jeśli dezerter zabrał ze sobą konia służbowego, na jego dzienną paszę wypadało przeznaczyć po dwa garnce owsa (w oryginale: deux metzes d'avoine) i osiem funtów siana wraz z niezbędną słomą. Koszty tej paszy miały być regulowane każdorazowo, według aktualnej ceny rynkowej tych towarów w najbliższym mieście.

Ponieważ złapanego dezertera należało zwrócić nie później niż osiem dni po aresztowaniu, które z kolei powinno nastąpić zaraz po jego odkryciu, dlatego rachunki za koszty jego utrzymania nie powinny przekroczyć okresu ośmiodniowego, chyba że przeniesienie z miejsca, w którym dezerter został pierwotnie aresztowany, lub inne dobrze umotywowane okoliczności stałyby się konieczną przyczyną opóźnienia jego ekstradycji po tymże ośmiodniowym terminie. Gdyby w wyniku choroby złapany uciekinier został przyjęty do szpitala ${ }^{44}$, koszty leczenia - które z tego tytułu mogłyby dodatkowo wyniknąć musiałby być pokrywane przez władze ponownie go przyjmujące w wysokości dwudziestu jeden groszy polskich dziennie; przez cały okres, w którym zły stan zdrowia nakazywał pozostawienie takiego uciekiniera w szpitalu.

Za odkrycie dezertera prawodawcy przewidywali w roku 1830 nagrodę. Mianowicie za wskazanie miejsca ukrywania się takiego uchodźcy, bez wzglę-

43 Tamże, s. 132.

44 Tamże, s. 133. 
du na rodzaj kategorii służby wojskowej danego żołnierza, ewentualnie nawet jeśli byłby to tylko osobnik podlegający obowiązkowi wojskowemu (tj. rezerwista czy rekrut) i doniesienie, że dany dezerter może zostać natychmiast aresztowany, donosiciel zostałby nagrodzony przez państwo, do którego nastąpi ekstradycja, sumą dwudziestu złotych polskich (to w wersji rosyjskiej, natomiast w oryginalnej wersji francuskiej podano: vingt-spet florin de Pologne). Jeśli donosiciel odkryłby jednocześnie zabranego przez uciekiniera konia służbowego i koń ten powróciłby do stanu posiadania państwa, do którego formalnie należał, nagroda ta zostałaby zwiększona do czterdziestu pięciu polskich złotych.

W celu natychmiastowej wypłaty nagród i pieniędzy za zatrzymanie oraz wyrównania kosztów utrzymania wymienionych w artykule 11-tym umowy kartelowej - które nota bene w żadnym wypadku nie mogły zostać podwyższone - zarówno Prusy, jak i Rosja, zobowiązały się do złożenia odpowiednich kwot na ręce swoich urzędników zajmujących się w wyznaczonych miejscach na granicy obu państw wydawaniem i przyjmowaniem zbiegów. Urzędnicy ci mieli zatem stale dysponować pewną ilością gotówki, z której to sumy pobieraliby środki na zapłacenie ,za dostawę” dezertera lub osoby podlagającej tylko obowiązkowi służby wojskowej, a także za zwracanego konia. Wskazany urzędnik musiał mieć oczywiście stale do dyspozycji gotówkę ${ }^{45}$ przeznaczoną na wypłatę nagród za doniesienie o uciekinierze czy za zatrzymanie/doprowadzenie dezertera czy zbiega i za koszty jego utrzymania, zgodnie ze specyfikacją przedstawioną na ręce takiego właśnie urzędnika w imieniu organu drugiego państwa odpowiedzialnego za ekstradycję. Nawet jeżeli okazałoby się, że taka specyfikacja była wadliwa (co jednak - podobnie jak w zapisach ustawy kartelowej z roku 1816 - uważano za wysoce nieprawdopodobne wobec dokładnego określenia stawek wynagrodzeń i kosztów utrzymania), także i wówczas płatność miała zostać dokonana w całości. Dopiero później bowiem, tj. na dalszym etapie postepowania, ewentualna skarga $\mathrm{w}$ tym temacie mogła zostać wzięta pod uwagę.

Takie rozpatrywane zastrzeżenia nie miałoby jednak miejsca: a) gdyby nie nastąpiło wydanie w pełni zgodne z treścią art. 9. konwencji kartelowej, dotyczącego jednoczesnego przywrócenia ekwipunku wojskowego, znalezionego 
przy dezerterze; b) gdy nie było przedstawienia wystawionego uprzednio „oryginału rekwizycji/wniosku o ekstradycję". W takim przypadku nie zostałoby wypłacone ani wynagrodzenie, ani nie miałby miejsca zwrot kosztów utrzymania.

Ponieważ dezerterzy i ludzie pełniący służbę wojskową nie mogli zaciągać na terytorium państwa, do którego uciekli, jakichkolwiek długów, za które musiałby prawnie odpowiadać rząd, „do którego należeli”, stąd takie zobowiązania pieniężne nigdy nie mogły być przedmiotem roszczenia ich zwrotu $\mathrm{w}$ jakimkolwiek postępowaniu pomiędzy organami administracyjnymi obu państw. Natomiast w wypadku jeżeli dezerter - osoba fizyczna - podczas pobytu w państwie następnie go wydającym zaciągnęła zobowiązania wobec innych osób fizycznych (a zatem, gdy jej ${ }^{46}$ ekstradycja faktycznie uniemożliwia dłużnikowi spłacenie swego zobowiązania), wówczas strona poszkodowana mogła dochodzić swoich praw jedynie przed właściwym organem państwa, do którego należał jej dłużnik. Podobnie, jeśli dezerter lub osoba podlegająca służbie wojskowej byliby w momencie złożenia wniosku o ich ekstradycję $\mathrm{w}$ areszcie $\mathrm{z}$ powodu zaciągniętych i niespłaconych długów wobec osób fizycznych, wówczas państwo otrzymujące takie żądanie wydania musiało je natychmiast spełnić.

Z kolei osoby, które na terytoriach podległych królowi pruskiemu lub carowi rosyjskiemu popełniłyby przestępstwo lub przynajmniej były oskarżone o popełnienie takiego czynu zabronionego, a następnie uciekałyby na teren podległy władzy drugiego z wymienionych władców, musiały zostać wydane przy pierwszej nadarzającej się procedurze rekwizycyjnej. Ustawodawcy wyraźnie przy tym wskazywali, iż przynależność stanowa lub kondycja społeczna danej winnej - czy oskarżanej tylko o winę - jednostki nie mogły w żaden sposób wpłynąć na ewentualne odstąpienie od wykonania tego przepisu/zalecenia. Powyższe oznaczało, iż (domniemany) winny musiałby być na żądanie wydalany, niezależnie z jakiego stanu społecznego by on pochodził (na przykład będąc szlachcicem), i niezależnie od tego, czy mieszkał w mieście, czy na wsi, czy był osobą wolną, czy znajdował się w grupie „poddanych”, czy był osobą wojskową, czy cywilną ${ }^{47}$.

46 Tamże, s. 135.

47 Tamże, s. 136. 
Ale jeżeli wspomniany przestępca lub oskarżony podlegał suwerenowi kraju, do którego uciekł po popełnieniu przestępstwa na terytorium drugiego władcy, jego wydanie nie mogło mieć miejsca. Zamiast deportacji, król pruski czy car rosyjski mieli obowiązek wymierzenia takiemu przestępcy natychmiastowej/szybkiej „sprawiedliwości” poprzez postawienie poddanego przed sądem. Jeżeli jednak jakakolwiek osoba została aresztowana w kraju, w którym popełniła przestępstwo lub jakikolwiek czyn o charakterze bezprawnym, a to poprzez popełnienie czynu zabronionego lub nadużycia, wówczas administracja państwa, w którym dokonano aresztowania, była władna nałożyć na takiego przestępcę stosowną karę, nawet jeśli taka osoba podlegałaby formalnie drugiemu władcy.

Wobec pojawiającej się potrzeby wydania takiego uciekającego przestępcy do drugiego państwa, obowiązkiem „sądu najwyższego" dla danej prowincji/guberni, w którym konkretny przestępca musiał być (lub był już uprzednio poddany dochodzeniu i gdzie został ewentualnie skazany) sądzony, powinno być wydanie wszelkich niezbędnych rozporządzeń ekstradycyjnych, które co do zasady - musiały zostać skierowane właśnie do „sądu najwyższego" prowincji/guberni, gdzie podejrzewano, czy miano pewność, że taki właśnie przestępca starał się o azyl. Gdyby jednak chodziło tylko o odkrycie miejsca pobytu danej ukrywającej się osoby i sprawdzenie jej za pośrednictwem służb porządkowych, można było w tym celu skierowywać wnioski do ${ }^{48}$ prowincjonalnych organów policji obu stron umowy kartelowej z 17/29 marca 1830 roku - tj. Rosji i Prus. Tak czy inaczej, we wszystkich przypadkach, gdy chodziło o ekstradycję przestępcy, wniosek przedkładany w jego sprawie musiał zawierać szczegółowe informacje o okolicznościach przestępstwa, tak, aby czytając podanie ekstradycyjne, można się było dowiedzieć czy uciekinier był przez stronę wnoszącą podanie oskarżony w taki sposób, „[...] że zgodnie z prawem państwa, do którego skierowana jest skarga, winowajca [...]" byłby „,...] również przedmiotem dochodzenia karnego”. Gdy tylko te warunki zostałyby spełnione, oraz gdy w wyniku przesłuchania, któremu oskarżony uciekinier byłby poddany, zostałaby bez wątpliwości dowiedziona jego tożsamość, należało takiego dezertera bezzwłocznie dostarczyć państwu-stronie wnoszącej o taką ekstradycję. W tym celu zostałby on eskortowany na granicę 
pod konwojem, a po zwrocie pieniędzy za poniesione koszty jego utrzymania i przetrzymywania, zostałby on przekazany odpowiednim władzom strony, która wymagała jego ekstradycji.

Uściślając kwestie finansowe, pruscy i rosyjscy ustawodawcy ustalili, iż od dnia aresztowania ściganego przestępcy, codziennie asygnowano po piętnaście groszy polskich brutto na jego utrzymanie oraz dwadzieścia dwa i pół grosza polskiego brutto dziennie za opłacenie kosztów pozbawienia go wolności i trzymania pod strażą.

Ani dezerterzy, ani osoby podlegające obowiązkowi służby wojskowej, ani przestępcy, nie mogli być ścigani przez władze państwa, które domagało się ich wydania „w kraju innego suwerena”, w drodze podjęcia jakiegokolwiek aktu przemocy, w sposób jawny ani ukryty ${ }^{49}$. Dlatego żadnemu oddziałowi wojskowemu lub grupie składającej się z cywili, ani tym bardziej nikomu potajemnie wysłanemu w celu ścigania takiego zbiega nie pozwalano na przekraczanie wspólnej granicy Królestwa Polskiego / Cesarstwa Rosyjskiego i Prus.

Jeśli zatem w celu schwytania jednego lub wielu dezerterów, ewentualnie osób podlegających obowiązkowi służby wojskowej lub tych, którzy uciekli przed odpowiedzialnością za popełnione przestępstwa, zostały wysłane ze strony państwa ścigającego oddziały wojskowe lub cywilne, wówczas taki pościg nie mógł rozciągać się dłużej niż do granicy rozgraniczającej obie strony konwencji kartelowej. W takim miejscu drużyna pościgowa musiała się zatrzymać, a tylko jedna osoba, której nie wolno było oczywiście używać żadnych aktów przemocy lub „okazywać oznak” jakiejkolwiek władzy, musiała skontaktować się z właściwym organem wojskowym lub cywilnym państwa - drugiej strony konwencji, w celu złożenia formalnego wniosku o ekstradycję, okazując zarazem „wymagane listy od swoich przełożonych”. Taki delegowany winien być przyjęty z należytym szacunkiem i uwagą, ,,[...] którą oba rządy są sobie winne", aby następie postępować zgodnie z warunkami umowy kartelowej z 1830 roku.

Każdy zatrzymany i aresztowany w tym kraju, którego granice przekroczył nielegalnie, musiał być - zgodnie z art. 19. omawianej konwencji prusko-rosyjskiej - postawiony przed najbliższym sądem, w którym prowadzone były dochodzenia w sprawie przestępstw wojskowych/przestępczości woj- 
skowej (w tekście rosyjskim: въ коемъ производятся следствя о военныхъ преступлешяхъ; $\mathrm{w}$ tekście francuskim: charge de information des delits militaires). Wyżej wskazany sąd podawał sprawę pod rozwagę, a po wysłuchaniu świadków prowadził dalsze postępowanie w takim zakresie, ${ }^{50}$ aby można było wydać wyrok. Następnie akta sprawy były przekazywane głównemu naczelnikowi wojsk/,szefowi wojsk” państwa, do którego należał podsądny w celu wydania postanowienia w sprawie, zgodnie z prawem danego państwa. Wyrok taki przekazywano do sądu prowadzącego dochodzenie, którego obowiązkiem było ogłoszenie go oskarżonemu, zatrzymanemu do tego czasu w areszcie. W zależności od treści tego wyroku, oskarżony zostawał albo niezwłocznie zwolniony, albo był dostarczany do najbliższych władz państwa drugiego w celu nałożenia odpowiedniej kary. Wszystkie czynności dotyczące prowadzenia sprawy należało wykonywać bez jakichkolwiek zakłóceń, przy możliwie sprawnym postepowaniu o charakterze przyśpieszonym. Jeżeli jednak sąd właściwy do wydania wyroku zażądał w trakcie postępowania dodatkowych wyjaśnień, informacje te musiały być dostarczone na wniosek tego sądu przez organ odpowiedzialny za poinformowanie o przestępstwie.

W przypadku wątpliwości co do samego naruszenia terytorium lub pojawienia się szczególnych okoliczności przekroczenia granicy, ustanawiano tzw. komisję mieszaną, gdzie przewodniczyli komisarze „strony poszkodowanej”, która wnosiła stosowną skargę. Głównym obowiązkiem tej komisji było ustalenie i podjęcie decyzji prawnej w zakresie określenia czy przekroczenie granicy państwowej było rzeczywiście nielegalne. Jak tylko decyzje podjęte przez tę komisję zostały potwierdzane przez przedstawicieli władców pruskiego i rosyjskiego, winowajcy wymierzano karę tak szybko, ,jak to możliwe”, zgodnie z prawem kraju, gdzie skazany miał daną karę odbywać50.

Było przy tym jasne, iż konwencja kartelowa z 17/29 marca 1830 roku surowo zabraniała „władzom i poddanym” obu stron umowy ukrywania ,[...] dezertera, osoby podlegającej służbie wojskowej”, w tym osobników, w stosunku do których już napłynęły roszczenia ekstradycyjne, czy co do których wydano orzeczenie w sprawie karnej. Nie wolno było pomagać tym ludziom w planowanym wyjeździe do krajów trzecich ,[...] w celu ochrony przed eks-

50 Tamże, s. 139.

51 Tamże, s. 140. 
tradycją". Rządy państw-stron umowy kartelowej musiały wytaczać postępowania ,zgodnie z prawem danego kraju” przeciwko osobom, które popełniły proceder ukrywania czy pomagania zbiegłym przez granicę dezerterem etc., a władze obu krajów zobowiązały się „dla swojej właściwej satysfakcji” do przekazania sobie nawzajem wszelkich informacji, dotyczących kroków podjętych w celu znalezienia winnych oraz o tym, w jaki sposób przestępcy zostali ukarani.

Jednocześnie art. 21. konwencji kartelowej z marca 1830 roku surowo zabraniał poddanym obu stron kupowania albo domagania się wydania od jakiejkolwiek osoby rzeczy, które niewątpliwie „nosiły na sobie znamiona” własności państwowej (państwa-drugiej strony konwencji). Zasadniczy zakaz i ostrzeżenie przed takimi działaniami dotyczył szczególnie ewentualnego zakupu koni, które dezerterzy mogli zabrać ze sobą podczas nielegalnego przekraczania granicy państwowej. Dodatkowo surowy zakaz zakupu obejmował jeszcze wszystkie przedmioty „[...] które zabrał przestępca podczas ucieczki i których jest nielegalnym posiadaczem”. Jednocześnie rządy petersburski i berliński zobowiązały się wzajemnie do wykorzystania wszelkich dostępnych im - zgodnie z obowiązującym prawem - środków celem bezpłatnego przykazywania sobie nawzajem wszelkich „uprowadzonych” przedmiotów, tak natury cywilnej, jak i sprzętu wojskowego ${ }^{52}$.

Potwierdzono też w roku 1830 rozwiązania, na podstawie których w wypadku braku ekstradycji dezertera, osoby przewidzianej do służby wojskowej lub przestępcy - jakkolwiek zgodnie z opisywaną tu konwencją kartelową takie wydanie powinno mieć miejsce - i gdy następnie wskazana osoba dokonała kolejnej ucieczki (do kraju, do którego powinna zostać pierwotnie dostarczona), władze tego kraju nie były zobowiązane do ekstradycji takiego osobnika.

Z kolei osoby, które w jednym lub drugim z obu państw-sygnatariuszy konwencji zostałyby uznane za „uciążliwe dla społeczeństwa”, nawet jeśli nie były tam obywatelami lub które nie miały tam stałego, przyznanego na podstawie prawnej miejsca zamieszkania, nie mogły zostać wydalone do innego państwa bez uprzedniej potwierdzonej zgody obu stron umowy, tj. Prus i Rosji. Podobnie było w wypadku, gdy taka osoba (,uciążliwa dla społeczeństwa”) lub jej rodzice urodziliby się na terenie państwa, do którego miała być wy-

52 Tamże, s. 141. 
słana, lub gdy wcześniej istniały między daną osobą a tym państwem relacje „poddania”, tj. gdy osoba ta była wcześniej obywatelem danego kraju.

Co więcej, jeżeli jedno z dwóch państw zamierzało przekazać „osobę uciążliwą" drugiej stronie umowy kartelowej, najbliższe władze prowincjonalne drugiego państwa musiały najpierw zadeklarować swoją gotowość przyjęcia takiego osobnika. Oznaczało to, iż bez uzyskania wcześniejszej zgody w danej sprawie ekstradycyjnej organy graniczne państw-stron umowy kartelowej nie miały ani prawa, ani obowiązku przyjęcia takiej osoby ${ }^{53}$.

Pozyskanie takiej zgody nie było jednak konieczne, gdy jedno z dwóch państw uznało za stosowne usunięcie ze swego terytorium osoby, której paszport został wydany na czas określony przez drugie państwo. Ponadto Rosja i Prusy zobowiązały się do przyjmowania takich osób bez jakichkolwiek trudności, nie tylko do czasu upływu terminu określonego w paszporcie, ale także, jeżeli taki paszport nie został odnowiony czy przedłużony do połowy pierwotnego okresu swojej ważności (i to tylko pod warunkiem, że taki całościowy okres nie przekraczał sześciu miesięcy).

Jednakowoż jeśliby obie strony uzgodniły przyjęcie danej osoby, państwo, które chciało doprowadzić do jej ekspulsji, musiało na własny koszt dostarczyć ją do granicy swojego terytorium. Specjalnie opisano tu też sytuację, gdy rząd Cesarstwa Rosyjskiego lub Królestwa Polskiego chciał „pozbyć się osoby”, której transport do jej ojczyzny / stałego miejsca zamieszkania mógł odbyć się wyłącznie tranzytem przez terytorium pruskie. W takim wypadku władze berlińskie nie miały prawa odmówić zgody na realizację takiego transportu (w tekście rosyjskim: прусское правительство никогда не откажется оть приняйя таковой пересылки на себя, w tekście francuskim: le gouvernement de Prusse ne refusera jamais son consentement a l'execution d'un pareil transport). Niezbywalnymi warunkami udzielenia pomocy ustanowiono jednakowoż przekazanie przy dokonaniu ekstradycji takiej osoby do pruskich organów granicznych: a) oświadczenia władz państwa, do którego formalnie należała transportowana osoba, wyrażającego zgodę na jej przyjęcie; b) pełnej kwoty pokrywającej koszty transportu i utrzymania takiego osobnika w czasie jego całościowej drogi do ojczyzny ${ }^{54}$. Gdyby dwa podane wyżej warunki nie zosta-

53 Tamże, s. 142.

54 Tamże, s. 143. 
ły całkowicie spełnione, władze pruskie - uwzględniając konwencje istniejące w tym względzie między Prusami a innymi państwami - nie były w stanie „pozwolić sobie” na przyjęcie osoby, którą należało przetransportować do państwa trzeciego ${ }^{55}$.

Z polskiego punktu widzenia najistotniejszym okazywał się fakt, iż do umowy kartelowej z 17/29 marca 1830 roku dołączono deklarację tej samej daty, również podpisaną przez hrabiów Alopeusa i Bernstorffa. W oświadczeniu tym stwierdzano przede wszystkim, iż władze Prus i Rosji, mając na uwadze występowanie znaczących różnic w zapisach ustawodawstwa kryminalnego obu krajów, uznały jednocześnie za stosowne nie wymieniać wyraźnie w podpisywanym właśnie przez ich pełnomocników traktacie kartelowym jakichkolwiek przestępstw politycznych. Pragnąc jednak doprowadzić do wypracowania wzajemnej zgody i współdziałania w przypadkach, gdy jeden z rządów rozbiorowych wystąpiłby do drugiego o ekstradycję osoby obwinionej o tego typu, tj. ,polityczne przestępstwa”, Aleopeus i Bernstroff uzgodnili między sobą trzy punkty oddzielnej deklaracji kartelowej. Stwierdzano w nich przede wszystkim (punkt pierwszy), iż pomimo faktu, że zarówno rząd petersburski, jak i berliński, nie poczyniły we wspomnianej konwencji formalnego zobowiązania do wzajemnej ekstradycji osób oskarżonych o przestępstwa o charakterze politycznym, to jednak władze pruskie i rosyjskie nie mogły przykładać w żadnym stopniu mniejszej wagi do politycznie motywowanych próśb o wydanie ściganych osób - i składanych zgodnie z charakterem każdego ze szczególnych wypadków - oskarżonych o tego rodzaju przestępstwa, które to prośby zostałyby im (wzajemnie) złożone przez jedno z tychże państw.

55 Tamże, s. 144. Archiwum Główne Akt Dawnych w Warszawie, Zespól Rady Administracyjnej Królestwa Polskiego, syg. 22/395-396. Zachowała się informacja o transporcie osoby deportowanej przez terytorium Królestwa Polskiego do kraju trzeciego. Otóż podczas 44. sesji Rady Administracyjnej, odbytej już po upadku powstania listopadowego, w początkowym okresie roku 1832, zwierzchnie władze rosyjskie poinformowały Rząd Tymczasowy w Warszawie o „[...] mającym nastąpić prowadzeniu przez Królestwo Polskie Turka Szalejmita, odsyłanego do ojczyny”. Rosjanie wzywali władze warszawskie o wypłacenie na koszta jego podróży na ręce „generała jazdy hrabi Witta [...]" stosownej kwoty pieniędzy. W konsekwencji Rząd Tymczasowy nakazał wskazaną powyżej decyzję przekazać do wykonania przez Komisję Rządową Przychodów i Skarbu. Jednocześnie rząd upoważnił KRPiS do nakazanie wypłacenia pieniędzy przewidzianych na pokrycie kosztów podróży deportowanego Turka. Przewidywano przy tym, iż tyko część żądanej kwoty zostałaby pokryta z zatwierdzonego uprzednio budżetu rocznego Królestwa, część natomiast zostałaby na ten cel przekazana z funduszu rezerwowego. 
Zastrzegano jednak zarazem we wskazanej deklaracji, iż przypadki naruszenia przepisów finansowych w żadnym wypadku nie byłyby zaliczane do kategorii przestępstw o charakterze politycznym. Poza tym Rosja i Prusy zastrzegały też sobie prawo do decydowania, - a to zgodnie z brzemieniem przepisów własnych - czy skarżone działanie, w przypadku którego jedno z tych państw wnioskowałoby o ekstradycję osoby fizycznej na podstawie uznania jej za groźną z politycznego punktu widzenia - musiało zostać zaliczone do klasy faktycznych przestępstw.

Deklarację tę sporządzono jedynie $\mathrm{w}$ dwu egzemplarzach (i przekazano sobie nawzajem przez pełnomocników), uznając zarazem, iż oświadczenie z 17/29 marca 1830 roku ,[...] będzie miało moc i wartość tylko wtedy, gdy zostanie dosłownie włączone do [...] umowy kartelowej" tej samej daty ${ }^{56}$.

Nie trzeba uzasadniać, iż dołączona do konwencji rosyjsko-pruska deklaracja o wydawaniu osób podejrzanych politycznie wprowadzała zupełnie nowy wymiar w relacjach ekstradycyjnych obu państw.

\section{Zakończenie}

Bez wątpienia podłoże pierwszej $\mathrm{z}$ omawianych $\mathrm{w}$ niniejszym tekście umów kartelowych (w zasadzie odnoszącej się w swoim pierwotnym założeniu do „zawracania dezerterów”) dotyczyło raczej zagadnień związanych z przemieszczaniem się armii jednego państwa przez terytorium państwa-drugiej strony kontraktu ( $w$ tym wypadku chodziło o wojska carskie poruszające się przez obszar państwa drugiego), stąd jego specyficzność. Należy przy tym pamiętać, iż wprowadzane w roku 1816 przepisy, dotyczyły - po stronie pruskiej - także członków Landwhery, dając przy okazji niejako carowi rosyjskiemu możliwość wprowadzenia w przyszłości podobnych formacji wojskowych i w Imperium Romanowych.

Wprowadzając zakaz rekrutacji przez przemieszczające się armie, przy generalnym wstrzymaniu się podczas ścigania dezercji zasady prawa działającego wstecz, ustawa z roku 1816 jasno precyzowała, iż osoby wojskowe pochodzące z byłego już wówczas Księstwa Warszawskiego miały zostać skie-

56 F. de Martens, Recueil des traits, t. 8, s. 144-145. 
rowane (o ile się temu nie sprzeciwiały i przy zachowaniu zasady pozostania w danej armii) do wojska tego państwa, w którego granicach - po Kongresie Wiedeńskim - znajdowało się ich miejsce urodzenia. Wreszcie umowa kartelowa z 13/25 maja 1816 roku zakładała zgłoszenie wniosku o poszukiwanie i wydania uciekiniera nie później niż w ciągu dwóch lat, licząc od dnia dezercji. Jasno też określono koszty utrzymania złapanych dezerterów jak też wysokość antycypowanej nagrody za ich wskazanie/dostarczenie oraz przewidywany czas jego wydania. Co równie istotne, w konwencji odniesiono się również do sposobu traktowania nadgranicznych włóczęgów czy wydalanych przestępców, dążąc do zapobiegania pogranicznemu włóczęgostwu.

Z kolei zawarta pomiędzy Rosją i Prusami w dniu 24 marca / 5 kwietnia 1817 roku dodatkowa umowa kartelowa skupiała się zasadniczo na kwestiach prawnych, związanych przede wszystkim z procedurami podejmowanymi w sprawach przestępstw związanych z naruszeniem terytorium, jak też z ustaleniem kosztów utrzymania dezerterów.

Przy relatywnie stałym zestawie kwestii podnoszonych w treści kolejnej rosyjsko-pruskiej konwencji kartelowej z marca roku 1830, gdzie dane zagadnienia omawiano z większą lub mniejszą szczegółowością, z reguły w niewielkim tylko stopniu zmieniając poszczególne konkretne zapisy, a jeszcze rzadziej dodając nowe - dotychczas nieporuszane - kwestie, na szczególną uwage zasługuje tu tajna deklaracja do opracowanej właśnie przez Davida d'Alopaeus'a oraz Christiana Günthera hrabiego de Bernstorff'a konwencji o wydźwięku odsłaniającym niejako nowy, najbardziej jednak istotny i ukryty zarazem cel podpisywania licznych już wówczas umów ekstradycyjnych. Otóż zagwarantowana dzięki zapisom tejże deklaracji (pomimo iż Petersburg i Berlin nie wprowadziły do podpisywanej konwencji formalnego zobowiązania wydawania podejrzanych o przestępstwa polityczne) możliwość ekstradycji „przestępców politycznych” odsłaniała oczywiście antynarodowowyzwoleńczy (antypolski) jej charakter. Taki właśnie tajny zapis deklaracyjny, opracowany i sporządzony na osiem miesięcy jedynie przed wybuchem powstania listopadowego, rzuca zupełnie nowe (jeśli nie powiedzieć nieznane) światło na kwestię ewentualnego antycypowania przez Rosjan czy Prusaków aktywności niepodległościowej polskiego społeczeństwa, czy na poszerzenie zakresu działania służb prewencyjnych obu państw zaborczych w stosunku do spodziewanej najwyraźniej polskiej „interrendy”. Konstatacja ta, poza wska- 
zaniem na oczywistą dalekowzroczność ówczesnych przedstawicieli dyplomatycznych Prus i Rosji, może też stanowić uzupełniającą przesłankę do oceny stosunku pruskich służb granicznych i administracyjnych do przekraczających granicę jesienią roku 1831 powstańców listopadowych, a szczególnie prób zmuszenia ich do powrotu na terytorium Królestwa.

\section{Bibliografia}

Alopeus graf David Maksimovitsch, [in:] Enciklopedideckij Leksikon, t. 2, Alm-Ara, Sankpetersburg 1835, http://www.rusdiplomats.narod.ru/alopeus-dm.html [dostęp: 22 marca 2020 roku].

Archiwum Główne Akt Dawnych w Warszawie, Zespól Rady Administracyjnej Królestwa Polskiego, syg. 22.

Bräuner R, Geschichte der preußischen Landwehr. Historische Darstellung und Beleuchtung ihrer Vorgeschichte, Errichtung und späteren Organisation, Zweiter Halbband, Berlin: Verlag von E. S. Mittler und Sohn, 1863.

Dziennik Praw Królestwa Polskiego, t. 6, Warszawa: Drukarnia Rządowa, [1820]. Hardenberg (Karol August książę de), [w:] Dykcyonarz biograficzno-historyczny, czyli, krótkie wspomnienia ludzi wsławionych cnotą, nauką, przemysłem, męstwem, wynalazkami, błędami, od początku świata do najnowszych czasów, t. 1, Warszawa: Gustaw Leon Gluckberg, 1844.

Haussherr H., Bußmann W., Hardenberg, Carl August Fürst von (preußischer Fürst 3.6.1814), [in:] 7 Neue Deutsche Biographie, 1966. [online version:] https://www. deutsche-biographie.de/gnd118545906.html\#ndbcontent [dostęp: 22 marca 2020 roku].

Kellenbenz H., Bernstorff, Christian Günther Graf von, [in:] 2. Neue Deutsche Biographie, Berlin: Duncker \& Humblot, https://www.deutsche-biographie.de/ ppn116147695.html [dostęp: 13 listopada 2020 roku].

Martens de F., Recueil des traits et conventions conclus par la Russie avec les puissances etrangers, t. 7, Traites avec l'Allemagne, St. Petersbourg: Tipografia Ministerstva Putej Soobscenja, 1855.

Martens de F., Recueil des traites et conventions conclus par la russie avec les puissances etrangeres, publie d'orde du ministere des affairs etrangeres, t. 8, 
Traires avec l'Allemagne 1825-1888, Sankt Perersbourg: Tipografia Ministerstva Putej Soobscenja, 1888.

Martens de G. F., Saalfeld F., Nuveau recueil des Traites d"Alliance, de Paix, de Treve, de Neutralitie, de Commerce, de Limites, d'Echange etc de plusieurs autres actes servant a la connoissance des relations etrangeres des puissances et etats de l'Europe tant dans leur rapport mutual que dans celui envers les puissances et etats dans d,autres parties du globe depuis 1808 jusqu'a present, t. 8, 1825-1830 incl., Gottingue: Libraire de Dieterich, 1831; https:// books.google.pl/books? id=e4gaAQAAIAAJ\&pg=PA244\&lpg =PA244\&dq=Chretien + Gonthier+comte ++ de + Bernstorff $\&$ source $=$ bl\&ots $=\mid c i i B L w t I g \&$ sig $=A C$ fU3U1Me8fAFBQuOxgbVAgVmxt5hkgmug\&hl=pl\&sa=X\&ved=2ahUKEwjuqOPhoLDoAhXykIsKHQIsC5IQ6AEwBnoECAQQAQ\#v=onepage $\& q=$ Chretien $\% 20$ Gonthier\%20comte\%20\%20de\%20Bernstorff\&f=false [dostęp: 11 sierpnia 2020 roku].

Sonthofen W., Der Deutsche Orden, 800 Jahre Geschichte Augsburg: Weltbild Verlag, 1995. 